\title{
Research and Practice of Welding Technology and Automation Professional Construction Based on Modern Apprenticeship
}

\author{
Yukun Yang \\ Tianjin Maritime college \\ Tianjin, 300350, China
}

\begin{abstract}
The purpose of this paper is to explore the joint training of school-enterprise integration and the standards and methods of modern apprenticeship. This paper analyzes the characteristics of modern apprentices, combines today's social needs, welding technology professional training standards, analyzes the elements and standards of modern apprenticeship, and proposes the key ways to combine modern apprentices with major construction. Finally, it concludes that the implementation of the modern apprenticeship program provides a good service platform for welding students and builds a bridge between schools and enterprises. Therefore, Modern apprenticeship is a new mode of talent training and an effective mechanism.
\end{abstract}

Keywords—Modern apprenticeship; Welding technology; Professional construction; Teaching reform

\section{INTRODUCTION}

Modern apprenticeship training places are composed of vocational schools and enterprises. The training targets are mainly graduated from high school. Compared with the German and Swedish models, the implementation of British modern apprenticeship is mainly determined by employers of enterprises. Develop the skills needed for the company. There is no standard training mechanism for modern apprenticeship training. All walks of life have established rules and regulations according to their own needs. In order to implement the spirit of the 19th Party Congress and accelerate the construction of a knowledge-based, skilled and innovative labor force, it is necessary to have appropriate The training system fully implements the new apprenticeship system. All walks of life can determine the training objects in combination with actual production, and adopt a training mechanism of "work-study integration, school-enterprise dual system". Enterprises, schools, vocational training institutions, and corporate training centers use the school-enterprise dualteachers to teach apprentices. This low-cost, large-scale, moderate-cycle school-enterprise talent training model has replaced the modern traditional apprenticeship talent training model [1], The vocational and technical college personnel training model has replaced the traditional apprenticeship talent training model and reduced the optimal cost of labor costs. It is the cooperation between enterprises and vocational colleges to cultivate talents. On August 1, 2018, the General Office of the Ministry of Education announced the notice of the third batch of modern apprenticeship pilot units, he faculty and In order to better implement and construct the modern apprenticeship system, the modern apprenticeship system is analyzed, summarized, and summarized as follows: "One program" modern apprenticeship pilot work implementation plan. "Two subjects" refers to the main purpose of the college, the enterprise subject, and the modern apprenticeship. One is to serve students and the other is to serve enterprises. The apprenticeship training objectives should be based on the high and intermediate technical personnel who meet the needs of the company. The training period is 1 year, and the special circumstances can be extended to 2 years. The main contents of the training include professional knowledge, operational skills, safe production scale and professional quality, especially The cultivation of craftsmanship. In enterprises, it is necessary to adopt the method of apprenticeship through corporate instructors, and the training institutions should adopt the integration of engineering and learning, and actively apply the "Internet + " and vocational training packages. The change of apprenticeship, the traditional apprenticeship of middle school students has only one identity apprentice, and the modern apprenticeship has two identities, namely students and apprentices. During the apprenticeship, we must adhere to the government's overall planning, adhere to cooperation and winwin, adhere to local conditions, adhere to system design, and focus on breakthroughs. The welding technology and automation majors mainly cultivate ideological and political firmness, morality and repair, comprehensive development, adapt to the needs of the modernization of socialism with Chinese characteristics and the development of science and technology. They have good ideological and moral character, professional ethics, teamwork spirit and innovative entrepreneurship. The quality, master the basic theoretical knowledge and professional knowledge necessary in the field of modern welding technology, cutting technology and automation, intelligent welding technology, with the actual operation of welding technology operation, welding process preparation and implementation, welding structure quality inspection and welding technology management The basic ability and basic skills of the work, for high-quality workers and technology in the field of welding technology for welding, cutting operators, welding process design and preparation personnel, welding quality inspection, welding production technology management and welding equipment after-sales service Skilled talent. 


\section{MODERN APPRENTICESHIP ELEMENTS AND STANDARDS}

Business instructors are obliged to guide apprentices' job skills, help apprentices master and improve skill levels and job requirements, and enable apprentices to have the ability to work in positions. During the training period, the apprentices shall pay the apprentices according to the labor law no less than the minimum wage standard of the place where the enterprise is located. The expenses incurred by the enterprise for job training and business training carried out by the apprentices may be subject to the education funds of the employees in accordance with the relevant policies. Expenditure. According to the relevant policies of the Ministry of Education on the Implementation of the Pilot Work on Modern Apprenticeship System, the school has established a pilot program for apprenticeship training, teaching methods, dual assessment, and dual identification. In search of cooperative enterprises, determine the apprenticeship level. , teacher training, system evaluation system.At present, the school has established a program of apprenticeship training, teaching methods, double assessment, and dual identity. It is looking for cooperative enterprises, determining apprenticeship level, teacher training, and developing evaluation system. Modern apprenticeship is a means of change in talent training mode. It is a means of change that makes subculture innovation in training mode, teaching mode, learning content, learning mode, appraisal and evaluation, employment and lifelong learning, and this kind of change will bring education field. a revolution. Therefore, it is necessary to build an interactive resource support platform and technology platform, expand the learning resources of different levels, establish credit banks, integrate curriculum and evidence, build a digital resource system and case database, build a multi-evaluation system, and jointly build a talent training program. The apprenticeship system emphasizes Enterprises must participate in the cultivation of talents from the very beginning.

\section{WELDING TECHNOLOGY AND AUTOMATION PROFESSIONAL TRAINING STANDARDS}

\section{A. Quality requirements}

Quality requirements to achieve path course ideological and moral cultivation and legal basis, education / mental health education, national defense military theory / etiquette education, employment guidance and innovation and entrepreneurship education / situation and policy social practice and lectures

\section{B. Knowledge requirements}

The knowledge requirement realization path is to set the course computer-aided design CAD, advanced operator-level test certificate, welding engineering foundation/welding method and equipment, welding electrical and electronic technology, welding automatic control technology, ship welding technology, ship-level welding specification and standard, etc. , welding methods and equipment / welding professional English / welding automatic control technology / post practice, welding methods and equipment, metal materials and heat treatment, welding engineering foundation, welding electrical and electronic technology / welding automatic control technology, PLC application technology / welding robot and $\mathrm{CNC}$ Cutting, equipment programming course implementation. And through practical training project $\mathrm{CAD}$ on-machine training, advanced operator-level exam certificate training, common welding methods, welding equipment, new automated welding technology training, familiar with and implementation of ship-level welding specifications, post-training, ship structure welding And craft, post internship, programming training, welding robot, $\mathrm{CNC}$ cutting equipment,

\section{Ability requirements}

Competency requirements by setting course ship structure and drawing, college English, professional English, advanced mathematics, metal materials and heat treatment, welding engineering foundation, welding electrical and electronic technology, welding automatic control technology, welding methods and equipment, PLC application technology, welding process Sensing and testing, arc welding power supply, ship welding fixture, welding engineering foundation, ship welding technology, welding engineering basic knowledge and other curriculum guarantees, and through practical training project CAD training, listening and conversation training, ship component force analysis, post practice, welding fixture design and production training, welding process training, ship welding quality inspection analysis and control project training reality.Welding technology and automation professional students' quality, knowledge, ability and skills are shown in figure 1. 


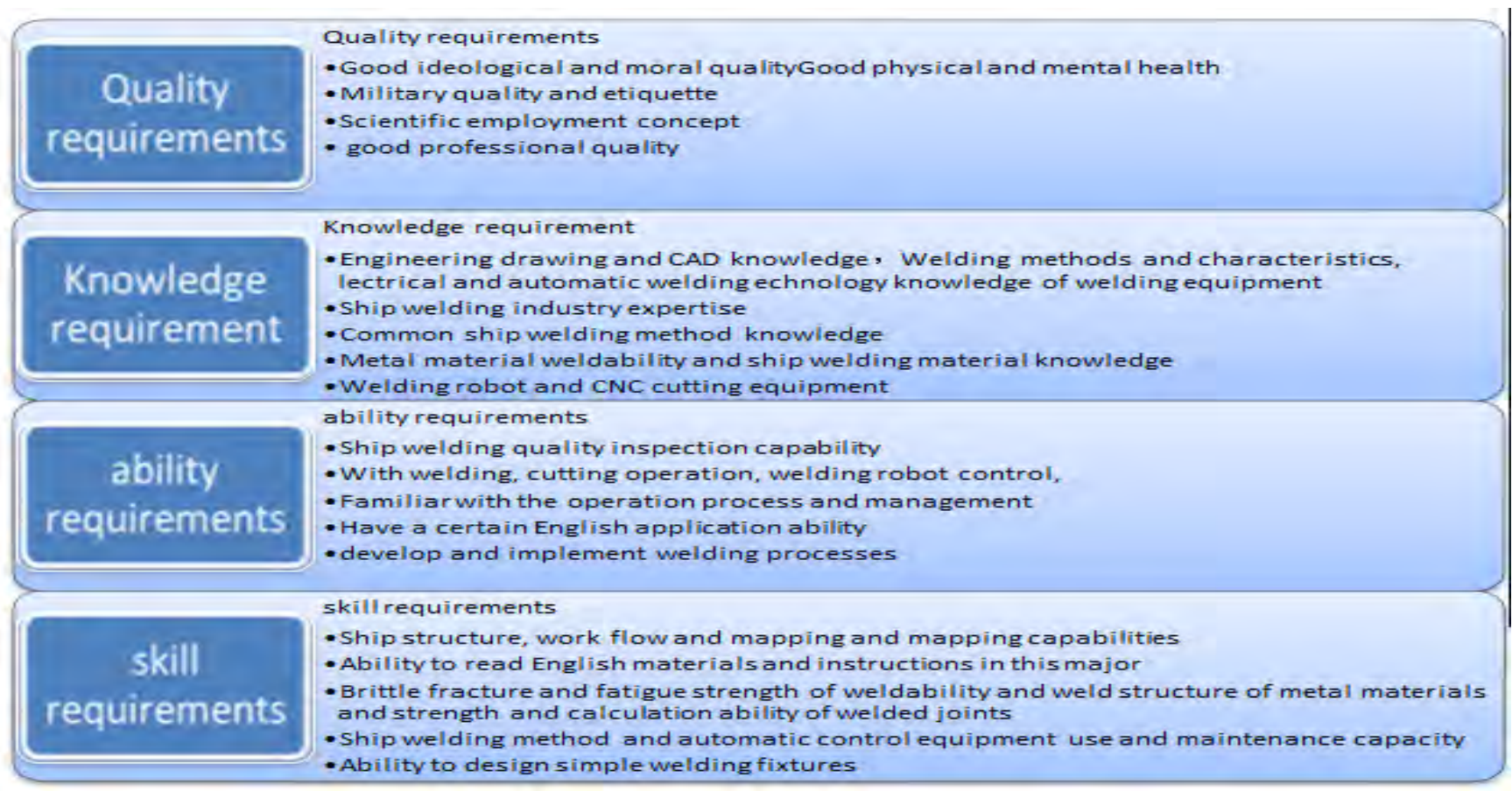

Fig. 1 Welding technology and automation professional requirements for students

\section{MODERN APPRENTICESHIP AND MAIN CONSTRUCTION INTEGRATION}

The modern apprenticeship system is a new combination of traditional apprenticeship system and school education system. The exchange of students and apprenticeships. In accordance with the principle of government guidance, enterprise-based, School participation, Recruitment is enrollment, enterprise enrollment, school-enterprise dualteacher joint training" as the main content of the new apprenticeship system, further play the role of the enterprise, through school-enterprise cooperation the pattern of engineering and learning, organize new apprenticeship training, increase the outstanding skills of enterprises, and strengthen the ranks of enterprise workers [2]. The modern apprenticeship system trains high-skilled talents. It is a normal teaching arrangement to undertake the curriculum teaching of the "base" and "base" part-time teachers outside the school. At present, higher vocational colleges are faced with "higher" and "professional". The modern apprenticeship adopts an flexible academic system and undertakes apprenticeship training. It encourages and supports apprentices to complete their studies in stages using their spare time. The alternation of "work" and "study"[1]change the teaching organization and management mode. The exchange of work and study is the main mode of modern apprenticeship school-enterprise cooperation in developed countries in the West. It is usually used in schools one to two days a week, and the rest of the time is in business. Or rotate between school and business every few weeks. Under this institutional arrangement, school teaching plays a role in cooperating with the company. Schools and enterprises jointly implement curriculum management, jointly evaluate the implementation effect of the curriculum and evaluate the performance of high-skilled personnel training, and provide management support for the cultivation of high-skilled talents in the modern apprenticeship system. Establish and improve the industry-university-research cooperation mechanism for vocational education [4]. A sound legal system clearly defines the rights and obligations between schools [5], governments, enterprises, and individuals. Thus the cost of cooperation in production, education [3], and research in simple vocational education. Establish a diversified cooperation model centered on capacity development. Establish a strategy of curriculum development based on student ability development and market demand. Establish a long-term mechanism for joint development of modern apprenticeship, including exploring the cost-sharing mechanism for talent cultivation and coordinating teaching resources: including on-campus training sites, public training centers, and enterprise training positions. The main contents of promoting the integration of enrollment and recruitment include the joint completion of the recruitment and enrollment integration program, the joint development and implementation of the program by the school and enterprise, and the implementation of various enrollment examination methods according to the characteristics of different students. Emphasis should be placed on standardizing the admissions and employment procedures of vocational colleges. According to the principle of two-way selection, apprentices, schools and enterprises sign a tripartite agreement. For apprentices who are under the age of 16 and under the age of 18, they are signed by schools, apprentices, guardians and enterprises. Agreement, agreement content: clarify the rights and interests of all parties and the specific positions of the apprentices on-the-job training, teaching 
content, rights and interests, and so on. Improve the education talent training mode with the combination of work and study as the core. First, it is conducive to strengthening the application orientation of vocational education, and establishing and improving the system of jointly training technical and technical talents between institutions and enterprises. Second, it is conducive to exploring ways and means to achieve a benign connection between theoretical knowledge learning and practical skills learning. This not only gives full play to the potential of students, but also promotes the team building of "double-type" vocational education teachers. Build a faculty team that is shared by school and enterprise and improve the dual tutor system. To clarify the duties and treatments of the dual tutors, the cooperative enterprises must select outstanding high-skilled talents as masters, and the masters should undertake the assessment of teaching tasks and enjoy the corresponding allowances. Establish and improve the teaching management system that is compatible with the modern apprenticeship system, ${ }^{[6]}$ formulate the credit system management method and the flexible academic system management method, and innovate the evaluation, evaluation and supervision system. The method of apprenticeship management includes scientifically arranging apprenticeships, assigning work tasks, ensuring reasonable remuneration for apprentices.

\section{ANALYSIS OF THE CURRENT SITUATION OF THEORETICAL TEACHING AND PRACTICAL TEACHING IN WELDING}

Students receive academic education in the school, and the professor's place in the theoretical class is also carried out in a fixed classroom. At the same time, there is a generally accepted but erroneous idea that "after knowledge learning, after repeated practice, you can master the ability and then learn to work". This idea is wrong, and the occurrence of learning is not the result of "teaching." The order of learning content and the manufacturing process of the industry are completely reversed. The masters in the company prefer young people who have not participated in any training, so as not to develop bad habits in the school. To be precise, learners must be exposed to typical events, and learning takes place through interaction. The welding profession is the same as other majors. There are many types of professional courses. Students have to complete 8 classes in the classroom at most, and have an average of 4 lessons at least. But the same face a problem, theory and practice are not combined. Practice is practice, theory is theory, and the theoretical things are forgotten in the process of practice. There are independent teaching plans and talent training programs in the welding professional teaching process, and the personnel training program and teaching plan are strictly implemented in the teaching process. The professional course arrangement of the welding profession can be said to be comprehensive, including the contents of the welding process, as well as the post-weld heat treatment and the quality inspection of the welding. But it also faces the problem of students absorbing efficiency during class. In addition to theoretical classes, professional courses also have practical exercises. In practice, students will be taught the use of various welding methods. Through practical exercises, students who are not well-study in theory classes are still very interested in practical classes. And some students have strong hands-on ability and can independently study. Every student is faced with employment problems before graduation. The common phenomenon is that I don't know

The necessity of implementing modern apprenticeship in welding profession. The content of the school is very scattered, and the things I have learned are not used for a long time, and will gradually fade away. The modern apprenticeship system is essentially a "business unit" vocational education model, which is "workplace learning" and "work-based" learning, that is, learning in practice and learning in experience reflection. The workplace scene is real, the real environment, the real technical requirements, the real work experience, is the learning of the hands, brain and heart, not the school-led "school-based" system. The development of the apprenticeship system has also undergone a period of change and reform in the historical period. After years of teaching implementation, the modern apprenticeship system has emerged. The historical reform of apprenticeship is shown in Table1

TABLE I APPRENTICESHIP REFORM

\begin{tabular}{|c|c|c|c|c|}
\hline item & Apprenticeship & apprenticeship & industrial apprenticeship & Modern apprenticeship \\
\hline Number & Several/ qualified worker & $\begin{array}{c}\text { Two or three } \\
\text { apprentices }\end{array}$ & $\begin{array}{c}\text { Several/ qualified } \\
\text { worker }\end{array}$ & worker and teacher \\
\hline standard & Social recognition & Guild recognition & Skilled worker & Skilled worker/teacher \\
\hline Apprentice time & Not fixed time & $5-7$ years & $5-7$ years & $3-4 y e a r s$ \\
\hline Teaching place & Workplace & Workplace & Workplace & Workplace and school \\
\hline
\end{tabular}

Enterprises (especially small and medium-sized enterprises) need high-quality employees, and hope to keep young people from leaving small cities by supporting local and community development. The apprenticeship provides students with a variety of academic and vocational education options. The survey found that young people and adults who have participated in apprenticeships are more likely to learn from the school, and they become more targeted than those who do not participate in apprenticeship training. more confidence in the future career development. 


\section{CONCLUSIONS AND PROSPECTS}

Highly in line with the rules of vocational education Students can do "learning in secondary school, situational learning, and individualized teaching" in the process of learning knowledge. The teaching place is not fixed, it can be a workshop construction site, or it can be a fixed classroom of the school. The training method is more flexible, and the theoretical knowledge is taught to students through fragmented teaching methods. students dual identity dual subject. The workplace and the learning place alternate with systematic long-term training. The participants have a contractual relationship with the employer and receive wages or allowances. Employers are responsible for providing training to trainees who can engage in a particular profession. Successful completion of the apprenticeship, apprentices can get a certain professional qualification, indicating that apprentices can be qualified for employment in a certain occupation or occupation group. Shortened the cycle of talent training and saved talent cultivation resources. Learning is not passively accepting external information, but actively constructing knowledge based on prior knowledge background. The theoretical knowledge taught in the school is relatively wide. When welding students are in class, there is no specific product model to enter the students' minds. When teaching some knowledge points to students, they always look very pale, and students sound boring. Under the influence of the modern apprenticeship system, students can truly participate in actual production, know the real things, and then learn the skills needed to produce physical products through physical objects, avoiding the re-pre-job training and internships of students after graduation. the process of. The company saves the cost of pre-job training and internships, and is therefore beneficial to the company.

\section{REFERENCES}

[1] Yuanyuan Wang, Mingqi.Wang Study on the Training Mode of Business English Professionals in Higher Vocational Education under the Mode of Modern Apprenticeship[J]. Education and Education Forum,2018(43):235-236.

[2] Lu Zizhou, Cui Yuting. The Status Quo, Problems and Prospects of Modern Apprenticeship Research in China[J]. Education and occupation,2018(20):45-51.

[3] Zhang Wei. Exploration of Training Mode of Higher Vocational Mechanical Talents Based on Modern Apprenticeship[J].Internal Combustion Engines \& Parts,2018(19):243-244.

[4] Zheng Chaowen, Guan Feiming. Politics and school-enterprise linkage, all-round cooperation, multi-master sports people - the exploration of high-skilled personnel training mode [J]. Occupation, 2016 (24): 32-34.

[5] Hu De.Exploration on the Construction of Talent Cultivation System of Modern Apprenticeship in Secondary Vocational Schools in Ethnic Areas[J]. Science Consulting (Educational Research),2016(12):32.

[6] Guan Jing.The Historical Evolution and Thinking of Western Apprenticeship[J]. Journal of East China Normal University(Educational Science Edition),2010,28(01):81-90 